\title{
ЋИРИЛИЦА И ЛАТИНИЦА У УКРАЈИНСКОМ ПРАВОПИСУ (ИСТОРИЈСКИ И САВРЕМЕНИ ПРЕГЛЕД)
}

Украјина је донекле слична Србији у том смислу што се географски граничемо са двама системима писања: на једном крају земље граничемо се с ћириличним, православним светом, а на другом - с католичким латиничним, а дијахронијски можемо посматрати како су утицаји ова два система подједнако снажни.

Историјски гледано, ми се налазимо између и на пресеку културних ареала, које је академик Никита Толстој звао „Рах Slavia Orthodoxa” и „Pax Slavia Latina” јер су земље садашње Украјине биле део две империје: Хабзбуршке и Руске, што је довело до различитих културних (језичких и верских) утицаја на развој и функционисање украјинског језика у различитим регионима. Овај сукоб се највише манифестовао у Галицији, која је од краја 18. па до почетка 20. века била део Хабзбуршке монархије.

Познати украјински лингвиста и преводилац И. Лучук као илустрацију наводи једну занимљиву историјску чињеницу: црквенословенски језик украјинског извода на нашем терену одувек се учио као матерњи књижевни језик, у Лавовској богословији се овај језик звао Lingua Ruthenica, али тамо нису увек сви желели да га уче. И. Лучук наводи сведочење Михајла Тершаковца: „Када је 1834. године Управа Богословије у Лавову наредила о. Илнитском да предаје студентима црквенословенски језик и да их научи читати ћириличне текстове, студенти су га дочекали с батинама и повиком: „Co to, chce nas zrobić Azjatami! Precz z nim, Mongołem, Tatarzynem!'

Током последња два и по века, било је више покушаја превођења украјинског језика у латинску графију: расправе из прве половине 19. века, памфлет „Азбука i abecadło” Маркијана Шашкевича и такозвани „Азбучни ратови”, пројекат Јосефа Иречека у Галичини из 1859. године, правописне расправе из двадесетих година 20. века те најновији трендови у украјинским интелектуалним круговима и још много тога. Постоје различите варијанте 
„латинизације” украјинске ортографије - старије и новије, мање или више успеле, али ниједна се не може сматрати потпуно задовољавајућом.

Прва стандардизована латинична абецеда за украјински језик била је заснована на пољском правопису и завршена 1834. године, када је Јосип Лозински предложио комплетан превод украјинског (русинског) језика на латиничну графију, написавши чланак о увођењу пољске абецеде («O wprowadzeniu abecadła polskiego do piśmiennictwa ruskiego») и објавивши књигу «Ruskoje wesile» (1835). Граматику Лозинског одобрио је Јернеј Копитар, али ни прво ни друго издање никад није било објављено. Истакнути културни радници из Украјине протестовали су против увођења латинице, а контроверза и дискусије око овог питања добила је у историографији назив „Азбучни рат”.

Упркос неуспеху у покушају замене ћирилице, овај се правопис повремено користио за штампање украјинских књига у Аустрији и Пољској у међуратном периоду, па чак и за време Другог светског рата.

Најпознатији и потпуно званичан био је пројекат чешког слависте Јосефа Иречика, објављен 1859. године у Министарству културе и образовања Аустријског царства. Према плану аутора, латинизација је требало да допринесе модернизацији украјинског језика тако што ће га ослободити архаичног црквенословенског и новог руског утицаја. Овај пројекат је био покушај бечких власти да преведу галицијско-украјински правопис на латиницу по чешком моделу и на основу чешког правописа - с дијакритичким знаковима усвојеним из чешке графије.

Уводећи службену политику бечке владе у језичку и културну сферу међу аустријске Словене, Ј. Иречек је такође тежио политичком циљу. Био је активан и утицајан члан Чешке конзервативне странке и присталица аустро-славистике, нове политичке доктрине. Промовишући аустро-славистику, представници чешке интелектуалне заједнице, укључујући познате чешке научнике, свесно или несвесно су учествовали и у укључивању других славенских народа вишенационалне Хабзбуршке монархије у сферу чешких интереса и чешког језичког и културног утицаја.

И. Франко и В. Симович одговорили су на овај догађај својим критичким примедбама. Такви ауторитативни славистички научници као што су П. Шафарик и Ф. Миклошич такође су проговорили против реформе Ј. Иречека. Миклошич, који је некада био идеолог превођења галицијско-украјинске ортографије у латинску графију, негативан став према овој реформи изразио је много година касније, у другом издању своје „Упоредне граматике словенских језика" (Беч, 1874), ослањајући се на верзију галицијско-украјинског правописа на основу ћирилице ,у духу Вука Караџића”, тако да ни овај покушај увођења латинице у украјински језик није успео.

Данас се у украјинском правопису званично користи само ћирилица, свако „за” и „против” латинице остају само занимљиве чињенице о историји украјинске културе, нарочито писања.

Постоје званични стандарди латинизације који се користе за преношење украјинских властитих имена у међународним документима и језицима на 
основу латиничне абецеде, па је 27. јануара 2010. године влада Украјине донела резолуцију којом се регулишу правила и одобрава табела транслитерације украјинске азбуке на латиницу.

Међутим, присталице идеје о коришћењу латиничне графије у украјинској ортографији нису одустале од покушаја да се постигне жељено. На крају 20. века настављене су дискусије о потреби реформисања украјинског језика. Главно питање у овој дискусији јесте облик ортографије. Постоје идеје о увођењу латинице као другог писма (као што је случај у српском језику); неки научници сматрају да би латинично писмо требало постати универзално средство латинизације украјинског језика (тј. заменити савремене стандарде латинизације и, ако је потребно, потпуно обављати функцију ћирилице). Већина варијанти предложених у 20. и 21. веку заснивају се углавном на чешким и хрватским правописима. Главним разлогом промене писма често се сматра потреба да се украјински одмакне од утицаја руског језика. Супротстављање ћириличног и латиничног писма попримило је облик свесне конфронтације националних атрибута. Не обухвата само писмо, већ се огледа и у сукобљавању језичких модела и врста књижевних стандарда, везаних за различите политичке и националне дискурсе. У суштини, правопис се све више користи као политичко средство.

Засада су створени и функционишу сајтови за коришћење латиничног писма у украјинском језику, нпр: latynka.tak, а креирана је и мобилна апликација Lučukivka, намењена за превођење украјинских текстова у складу са правописом који је створио И. Лучук. Јавном мњењу се намеће идеја о потреби увођења латиничног писма, али, према нашем мишљењу, она још увек нема много изгледа да се реализује јер већи део становништва Украјине и говорника украјинског језика (а то нису само Украјинци, него и припадници других националности) ћирилицу доживљава као изворно писмо и средство за очување националног, верског, језичког и културног идентитета.

Међутим, морамо напоменути да се у садашњем историјском тренутку, откада је Украјина постала независна држава, украјински стандардни језик налази у фази промена и формирања нове норме.

Од 22. маја 2019. године важи нови правопис који, између осталог, регулише и писање позајмљеница и страних имена, пре свега ради се о интернационализмима грчког и латинског порекла, поготово онима који су одавно ушли у лексички систем украјинског језика и имају већ утврђени облик.

Овај правопис дозвољава дублете авдиторія / аудиторія , ефip / emep, Aфiни / Атіни, Георг / Георг, Вергілій / Вергілій и др. Нови правопис инсистира на томе да су дозвољени дублети, те се уводи варијабилност у норму. Поменула сам тај најнови правопис зато што он потврђује тенденције у украјинистици, а и у украјинском друштву, да се норме помало крше и да нису више толико строге.

Урадили смо мали мониторинг званичних изјава познатих и утицајних украјиниста и можемо констатовати да је такво толерисање дублета и варијантности у тренду. Важно је, на пример, видети званични став директора 
Института за лингвистику Националне академије наука Украјине (НАНУ), директора Бироа лингвистичких експертиза НАНУ и једног од чланова Комисије за правопис - проф. Богдана Ажњука (Богдан Ажнюк) јер је он чувени стручњак из области транслитерације, проблема језичке политике, лингвистичке експертизе и сл. У раду „Лингвистички аспекти глобализације” проф. Ажњук заступа следеће тезе:

Због глобализације се повећава присутство енглеског језика у информативном и комуникативном простору Украјине;

Енглески језик утиче на украјински у свим стиловима и регистрима;

Пребацивање језичких кодова појачава тенденцију ка повећавању интертекстуалности, која слаби норму, смањује осећање говорника да крши норму.

Богдан Ажњук тврди да, иако због глобализације постаје флексибилнија, норма делује као импулс за обнављање и развој језика, чини украјински језик модернијим те прилагођава језик новим условима, у којима он данас функционише. Из тога проистиче да се у Украјини данас толеришу непреведени и нетранслитерисани исписи страних фирми - назив бренда остаје исти као и у оригиналу свуда осим у статутним документима предузећа, јер се за регистрацију тражи да буде поред латиничног уписан и назив ћирилицом (то је неопходно само у фази регистрације, али никако у реклами и јавној употреби).

Латиницом се пишу не само имена страних брендова већ и домаћих Hпр: ROSHEN и др. Сматра се да је то боље за рекламу, да делује модерније, да упућује на квалитет робе (као да је увозна) итд. Велики део украјинских предузећа има енглеска имена, а и велики број часописа користи енглески језик како у називима тако и у насловима, али с текстом на украјинском језику "ArtLine", "Hotline”, "InternetUA", "MobileRadio", "Visual\&Verbalarts", "Motornews", "Parents", "PCWorldUkraine" и др.

У украјинском Закону о интелектуалној својини и регистрацији лога питање писма уопште није регулисано.

Ћирилица остаје (поред латиничног облика) само у исписима страних фирми који су одавно дошле на тржиште, још у време Совјетског Савеза: нпр: Сименс, Кольт, Рено и Кока-Кола, јер су они код говорника украјинског језика већ адаптирани, доживљавају се као домаће речи, мада и ове фирме данас у рекламама све више користе латинично писмо.

Све у свему, можемо да приметимо да у савременом тренутку питање писања назива страних брендова није актуелно у украјинистици и није често предмет лингвистичке расправе јер је језичка норма доста флексибилна и толерише латинично писмо у јавној употреби. Можемо претпоставити да такво слабљење норме може у будућности олакшати увођење латинице у украјински правопис. 
Ниједан покушај увођења абецеде до сада није дао резултат јер је још увек доминантно мишљење да не треба нарушавати или мењати вишевековну културну традицију украјинског писања.

\section{ЛИТЕРАТУРА}

Ажнюк Б. Лінгвістичні аспекти глобалізації в Україні // Мовні конфлікти і гармонізація суспільства. - Київ, 2002 . С. 144-150.

Ажнюк Б. Інновації в системі української мови та тенденції її розвитку // Освіта і управління. 2008. №11. С. 37-42

Бирюков С.В. Австро-Венгерская империя, генезис национальных движений и русинский вопрос // Русин. 2018. № 3 (53). С. 193-209.

Вендланд А.В. Русофіли Галичини. Українські консерватори між Австрією та Росією, 1848-1915. Львів, 2015. 688 с.

Лучук I.Українська латинка. Чому таки лучуківка. ZAHID.NET. 28. 06.2017. https://zaxid.net/ukrayinska_latinka_n1429706

Миллер А.И., Остапчук О.А. Латиница и кириллица в украинском национальном дискурсе и языковой политике Российской и Габсбургской империй // Славяноведение. 2006. № 5. С. 25-48.

Мойсеєнко В. Про одну спробу латинізації українського письма // Культурологічний часопис «Ї». Львів, 1997. № 9. С. 140-147.

Савчук Б.П., Билавич Г.В. «Азбучные войны» 30-50-х гг XIX в. в Галиции в современном научном дискурсе // Русин. Т.56. 2019. С. 58-76.

Толстой Н.И. Slavia Orthodoxa и Slavia Latina - общее и различное в литературно языковой ситуации (опыт предварительной оценки) // Вопросы языкознания .1997 . Вып.2. С. 16-24.

Чрділелі Т. В. Специфіка перекладу назв торгових брендів- Матеріали VI Міжнародної 132 конференції «Наука в інформаційному просторі», 2010. http://www.confcontact.com/20100916/iya_chrdi.htm

Олга Новак

\section{КИРИЛЛИЦА И ЛАТЫНЬ В УКРАИНСКОЙ ОРФОГРАФИИ (ИСТОРИКО-СОВРЕМЕННОЕ ОБОЗРЕНИЕ)}

Резюме

В статье рассматриваются попытки введения латинской графики для украинского языка. Констатируется, что в течение последних двух с половиной веков такие попытки предпринимались неоднократно, причем в XIX веке такие реформы правописания предлагались по инициативе Габсбургской империи, в состав которой входила Галичина, однако, ни одна из таких попыток не увенчалась успехом. В последние десятилетия в Украине возобновилась дискуссия о возможности и даже необходимости перехода на латинскую графику, что является политиче- 
ски обусловленным явлением. На современном этапе украинский литературный язык подвергается реформированию, старые литературные нормы ослабляются, в правописании увеличилась доля допускаемых дублетов и орфографических вариантов. Такой процесс ослабления нормы, а также влияние неадаптированных англицизмов в эпоху глобализации может привести к полной перестройке орфографической базы украинского языка и введению латинской графики.

Ключевые слова: украинский язык, орфографические нормы, кириллическое письмо, латинская графика. 